\title{
非一様地表面加熱場に生じる エネルギーインバランス \\ LES STUDY ON THE ENERGY IMBALANCE PROBLEM FOR HETEROGENEOUS SURFACE
}

\author{
稲垣厚至 1 ・神田学 $2 \cdot$ マレコス・オリバー・レッツエル3 \\ ・ジークフリード・ラッシュ 3 \\ Atsushi Inagaki, Manabu Kanda, Marcus Oliver Letzel and Siegfried Raasch \\ 1学生員 東京工業大学 理工学研究科土木工学専攻 (T152-8852 目黒区大岡山2-12-1) \\ 2正会員 工博 東京工業大学 理工学研究科国際開発工学専攻（T152-8852 目黒区大岡山2-12-1） \\ 3 ドイツ ハノーバー大学 気象気候学科
}

\begin{abstract}
The so-called energy imbalance problem is investigated through numerical experiments using Large Eddy Simulation (LES). LES experiments are done for daytime atmospheric boundary layers over a flat surface with inhomogeneous heat flux. The heat flux is represented by a one-dimensional sinusoidal curve with a variable wavelength and amplitude.

The following are the main results. 1) When the amplitude is enough, the bias and variance of imbalance is increase. A weak inhomogenity of surface heating, however, may relax the negative bias of imbalance. This is attributed to the heat transport efficiency of vertical mean wind. 2) Although longer wavelengths generally give a smaller bias of imbalance, the $2 \mathrm{~km}$ wavelength singularly increases the bias of imbalance. 3) The bias and variance of imbalance decrease in accordance with horizontal wind. Longer averaging time gives a smaller bias but a larger variance of imbalance. The tendency of these two results is almost the same as in the homogeneous heating case.
\end{abstract}

Key Words : imbalance problem, heterogeneous surface, Large Eddy Simulation model eddy correlation method

\section{1.はじめに}

現在観測研究において、点計測乱流に基づく渦相関法 によるフラックスの算定が多く行われているが、近年の 観測研究による結果より ${ }^{12)}$ 、この值は熱収支を満たさな い、特に過小評価する傾向があることが確認されてきた。 これがインバランス問題と呼ばれるものであり、観測 デー夕の信頼性に関わる重要な問題である。この問題に 対し、神田・渡辺 (2002) ${ }^{3)}$ 、神田 (2002) ${ }^{4)}$ はLESを用い た数值解析によって検討しており、これにより計器の影 響や場の不均一性などによる観測誤差に依存しない水平 一様な空間に生じるインバランスの基本的な性質につい てはほぼ明らかにされた。

そこで本研究はその研究結果をふまえた上で、水平方 向に非一様性を与えた場に生じるインバランスについて の検討を行った。場に非一様性を持たせる方法として、 底面加熱を一様に与えるのではなく水平方向に正弦関数
で変化させた。これにより強い加熱を受ける部分と弱い 加熱部分が存在するような不均一な場がつくりだされる。 実空間のイメージとしては、起伏のない平らな地表面で あるが雲があるため局所的な日射を受けるような状況や、 地表面パラメータが異なるような場を想定している。

このような非一様な加熱を受ける場において、主に以 下について検討を行つた。

(1) 非一様加熱特有である局所的な加熱の強さ、加熱 パターンの細かさなどがインバランスに与える影 響について検討する。本研究では加熱パターンを 正弦関数で変化させて与えているので、前者につ いては加熱振幅を、後者については加熱波長を変 化させて行う。

(2) 一様加熱場でのインバランスが持つ基本的な性質 が非一様加熱場に対しても一般的であるか検証す る。具体的には水平一般風の存在する場合や、異 なる乱流平均化時間を用いた時に生じる変化など について検討する。 
表-1 共通計算条件一覧表

\begin{tabular}{|l|l|}
\hline 領域 $(x-y-z)$ & $8 \mathrm{~km}-8 \mathrm{~km}-2.8 \mathrm{~km}$ \\
\hline 空間解像度 & 水平·鉛直ともに $50 \mathrm{~m}$ \\
\hline 時間解像度 & $0.4 \mathrm{sec}$ \\
\hline 格子点数 $(n x-n y-n z)$ & $160-160-50$ \\
\hline 解析高度 & $100 \mathrm{~m}$ \\
\hline
\end{tabular}

表-2 計算例一覧表

\begin{tabular}{|l|c|c|c|}
\hline \multicolumn{1}{|c|}{ Case } & $\begin{array}{c}\text { 波長 } \lambda \\
(\mathrm{km})\end{array}$ & $\begin{array}{c}\text { 振幅 } A \\
(\%)\end{array}$ & $\begin{array}{c}\text { 一般風 } \\
(\mathrm{ms}-1)\end{array}$ \\
\hline HW0 & 0 & 0 & 0 \\
\hline $\mathrm{HW} 1-8$ & 1 & 80 & 0 \\
\hline $\mathrm{HW} 2-1$ & 2 & 10 & 0 \\
\hline $\mathrm{HW} 2-4$ & 2 & 40 & 0 \\
\hline $\mathrm{HW} 2-8$ & 2 & 80 & 0 \\
\hline $\mathrm{HW} 4-2$ & 4 & 20 & 0 \\
\hline $\mathrm{HW} 4-8$ & 4 & 80 & 0 \\
\hline $\mathrm{HW} 8-8$ & 8 & 80 & 0 \\
\hline $\mathrm{HW} 4-2 \mathrm{u} 2$ & 4 & 20 & $2(\mathrm{x}-$ dir $)$ \\
\hline $\mathrm{HW} 4-2 \mathrm{v} 2$ & 4 & 20 & 2 (y-dir) \\
\hline
\end{tabular}

\section{2. 理論的背景}

$w$ を鈆直風速 $\left(\mathrm{ms}^{-1}\right) 、 T$ を温位 $(\mathrm{K})$ とすると任意地点 におけるある瞬間の顕熱フラックスは次のようにおける。

$$
F=w T
$$

そして式(1)の $w$ と $T$ を次のように時間平均成分とそこ からの乱れ成分に分解する。

$$
\begin{aligned}
& w=\bar{w}+w^{\prime} \\
& T=\bar{T}+T^{\prime}
\end{aligned}
$$

ここで一は時間平均操作を表す。これらを式(1)に代入 し、それにレイノルズ平均を適用すると、次の式(3)が 導かれる。

$$
\bar{F}=\bar{w} \bar{T}+\overline{w^{\prime} T^{\prime}}
$$

この式 (3) の右辺第 2 項が渦相関法によって求まる乱流 フラックスである。さらに式(3)に空間平均操作を施す と次のようになる。

$$
[\bar{F}]=[\bar{w} \bar{T}]+\left[\overline{w^{\prime} T^{\prime}}\right]
$$

口は空間平均操作を示す。この式(4)より、領域の熱収 支を満たす空間平均的なフラックス (左辺) は、平均流が 担う正味の熱輸送 (右辺第 1 項) と乱流が担う熱輸送 (右 辺第 2 項)の和であることが分かる。つまり空間平均し ても依然として残る平均流熱輸送項のため、乱流フラッ クスを厳密に空間平均しても空間平均的なフラックスと は一致しない。

ここでインバランス量と、それを正規化した值である インバランス率を次のように定義する。

$$
\begin{aligned}
& i b=\overline{w^{\prime} T^{\prime}}-[\bar{F}] \\
& i b r=\left(\overline{w^{\prime} T^{\prime}}-[\bar{F}]\right) /[\bar{F}]
\end{aligned}
$$

本研究で直接計算されるのは $w$ と $T$ の值であり、上記 の手順に従い各種フラックスやインバランスを計算する。
ここで式(5)を空間平均し、そこに式(4)を代入すると 次の関係が得られる。

$$
[i b]=-[\bar{w} \bar{T}]
$$

通常 $w$ と $T$ は正の相関があることから式(7) の值は負と なる。つまりフラックスを過小評価する傾向があるイン バランス問題の理論的原因は、平均流が担う正味の熱輸 送量であることが分かる。

\section{3. 数值実験概要}

\section{(1) LESモデル}

本研究は日中の対流混合層を数值モデルにより再現し、 実際の観測場と見立てて解析していく。その数値モデル

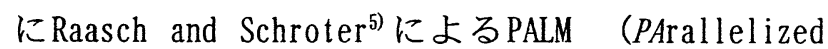
Large eddy simulation Model)を用いた。これはLESを 並列計算するようコーディングされたモデルであり、そ

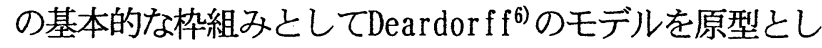
たものである。

\section{（2）計算条件}

直方体型の3次元空間を日中の大気境界層とみなし、 起伏の無い平坦な地表面から鉛直方向へ顕熱フラックス を供給する。そのときに妨向には式(8)に示すように正 弦関数で変化を与え、y方向には一様となるような縞状 の加熱を与えた。

$$
F_{g \nu}(x)=F_{g}+F_{g} A \sin \left(\frac{2 \pi}{\lambda} x\right)
$$

$A:$ 加熱振幅(\%), $\lambda:$ 加熱波長 (m)

$x:$ 距離(m)

$F_{g}:$ 正味の顕熱フラックス $\left(=0.1 \mathrm{Kms}^{-1}\right)$

これを実際の観測場に見立てるなら、畑のような一方 向に同じ地表面条件が続く場や、筋状の雲の切れ間から 日射が差し込むような場などを想定することができる。

初期の温位勾配は、日中の典型的な值（上空 $1 \mathrm{~km}$ まで $0.0008\left(\mathrm{~K} \mathrm{~m}^{-1}\right)$ それ以上で0.0074 $\left.\left(\mathrm{K} \mathrm{m}^{-1}\right)\right)$ とし、水平方 向に一様となっている。境界条件は、水平方向には周期 境界条件を用い、上端にはレーリ層を設け重力波を吸収 させている。また総観場での上下降流は無く、任意時間 で $[w]=0$ となる。

また発達しうる大気境界層高度は加熱振幅や加熱波長 に依らずどれも約1200m程度である。これは本計算が模 擬している、良く晴れた日中に発達する境界層高度と なっている。

積分時間は各解析例において5時間計算したが、始め の2時間は統計的に準定常化するのに使われるため、残 りの3時間のデー夕を解析に用いた。解析対象となる水 平断面高度は大気混合層内である高度100mとした。主な 共通計算条件及び、各解析例でのパラメー夕の設定值を それぞれ表-1，表-2に示す。 


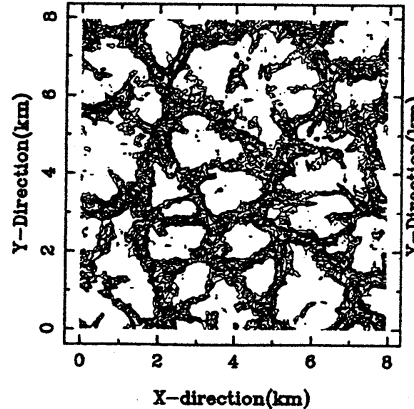

(a) 振幅0 (HWO)

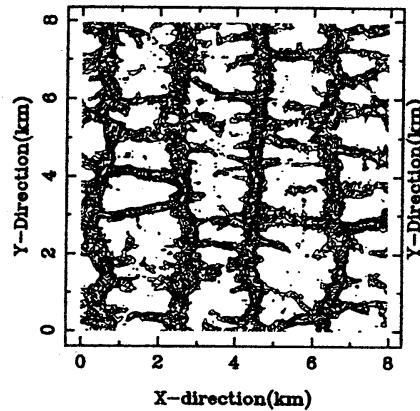

(c) 振幅 $40 \%$ (HW2-4)

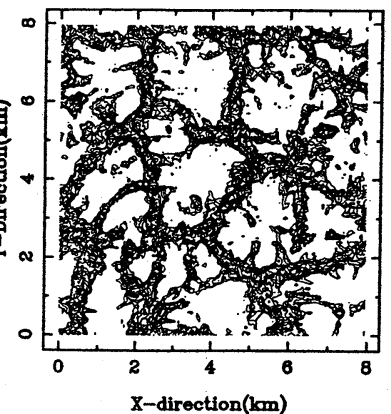

(b) 振幅10\% (HW2-1)

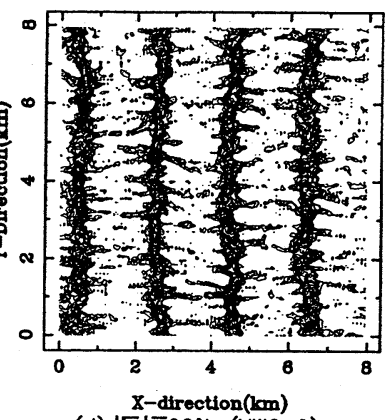

(d) 振幅 $80 \%$ (HW2-8)
図-1 平均鉛直風速分布 (上昇流域)

\section{4. 実験結果}

\section{（1）加熱振幅の影響}

式(8)の加熱振幅 $A$ を変化させ、加熱の不均一性の強 さによってインバランスがどのように変化するか調べる。

まず図-1の正の平均鉛直風速分布 (コンター間隔 $0.1 \mathrm{~ms}^{-1}$ )を見ると、一様加熱(図-1 (a))では亀の甲羅状の サーマルが形成されていたが、強い不均一性を持った縞 状の加熱(図-1 (c), (d))ではその構造があばら骨のよう な形となっており、加熱の強い部分 $(x=0.5 \mathrm{~km}, 2.5 \mathrm{~km}$, $4.5 \mathrm{~km}, 6.5 \mathrm{~km})$ では強い平均鈶直流が生じている。加熱の 不均一性に対応して生じる2次的なメソ循環による熱輸 送の効果は平均移流項の中に現れるため、直感としては 加熱振幅 $A$ が大きいほど平均流による熱輸送、つまり インバランスが増大すると考えられる。

図-2のインバランス率の確率密度分布を見ると、確か に大きな加熱振幅のときは負のインバランスが多く発生 していることが見られる。しかし小さな加熱振幅 $(0 \%$ 40\%)ではこの図からは一概に判断することはできない。

そこで次に図-3のインバランス率の断面空間平均値 $[i b r]$ を見てみる ( $\lambda$ : 加熱波長)。先の直感に従うなら、 加熱の不均一性が増大するに従い $[i b r]$ も増えると考え られたが、 $[i b r]$ が下限値をとるのは加熱振幅が若干の 不均一性があるときであり、これに反する。これらにつ いて以下検討を行う。

図-3においてインバランス率の変化が最も顕著な加熱 波長 $2 \mathrm{~km}$ のケースに着目する。インバランスの空間平均 值は式(7)で示されるような関係があり、 $\bar{w}, \bar{T}$ の值と 両者の相関によって決まるので、それらを詳しく見てい

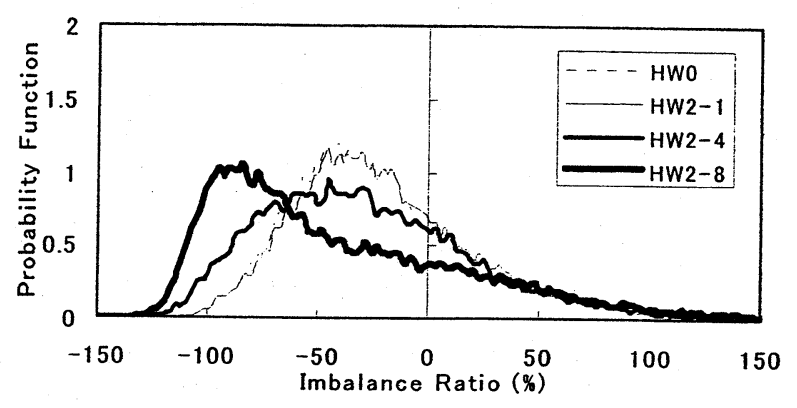

図-2 インバランス率の確率密度分布

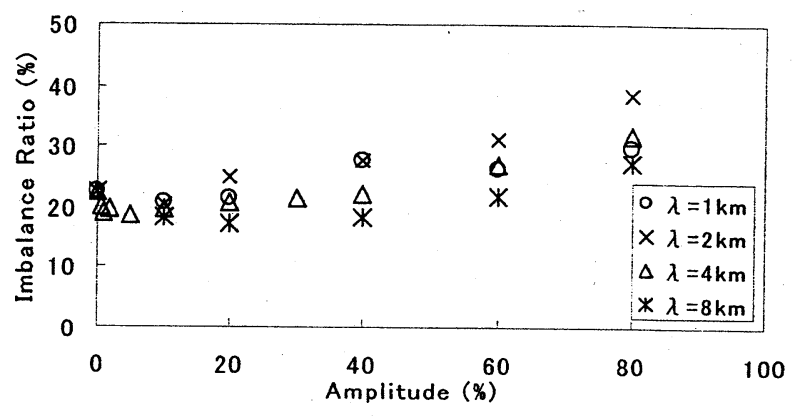

図-3 空間平均インバランス率と加熱振幅の関係

くことにする。図-4はそれぞれ $\mathrm{y}=4 \mathrm{~km}$ の位置における (a) $\bar{w}$, (b) $\bar{T}$, (c) $\bar{w}$ と $\bar{T}$ の相関のx方向変化を示す図で ある。相関については以下の式より導いた。

$$
\rho_{x}=\frac{\left(\bar{w}_{x}-[\bar{w}]\right)\left(\bar{T}_{x}-[\bar{T}]\right)}{\sigma_{\bar{w}} \sigma_{\bar{T}}}
$$

$\sigma_{\bar{w}}: \bar{w}$ の標準偏差, $\sigma_{\bar{T}}: \bar{T}$ の標準偏差

まず図-4 (a) (b)を見ると $\bar{w} 、 \bar{T}$ ともに加熱の強い部 分で大きな值を示しており、加熱振幅が大きくなるにつ れその值が少し大きくなる傾向が見られる。しかし常に $[\bar{w}]=0$ であることや、インバランスは平均流相関項で あることからこれら個々の值でそれを議論するのは不十 分である。そこで両者の相関を取った図-4(c)を見てみ る。そもそも式(9)の意味は平均鈶直流 $\bar{w}$ にるる熱の輸 送効率を示している。この図から加熱の強い部分に大き な正の相関が見られ、つまり平均鉿直流による熱の輸送 は主に加熱の強い部分に生じる上昇流が担っていること が分かる。そしてより強い振幅を与えた例(HW2-8) では 輸送効率はより大きな値を示している。つまり加熱振幅 が大きい場合、上昇流域 (強加熱部)における平均流熱輸 送量が正味の熱輸送量を増加させるほど大きくなり、そ のためインバランス率が上昇したと考えられる。

では加熱振幅の弱い例 (HW2-1) ではどうであろうか。 再び図-4(c)に着目すると、HW2-1の強加熱部における值 は先ほどのように大きくなく、正味の熱輸送量を左右す るほどの值ではない。つまり加熱振幅の弱い例では強加 熱部が場全体での平均流熱輸送を支配するのではなく、 他の部分を含めた輸送効果の影響が効いてくる。つまり 場全体での平均流熱輸送を考慮する必要がある。 


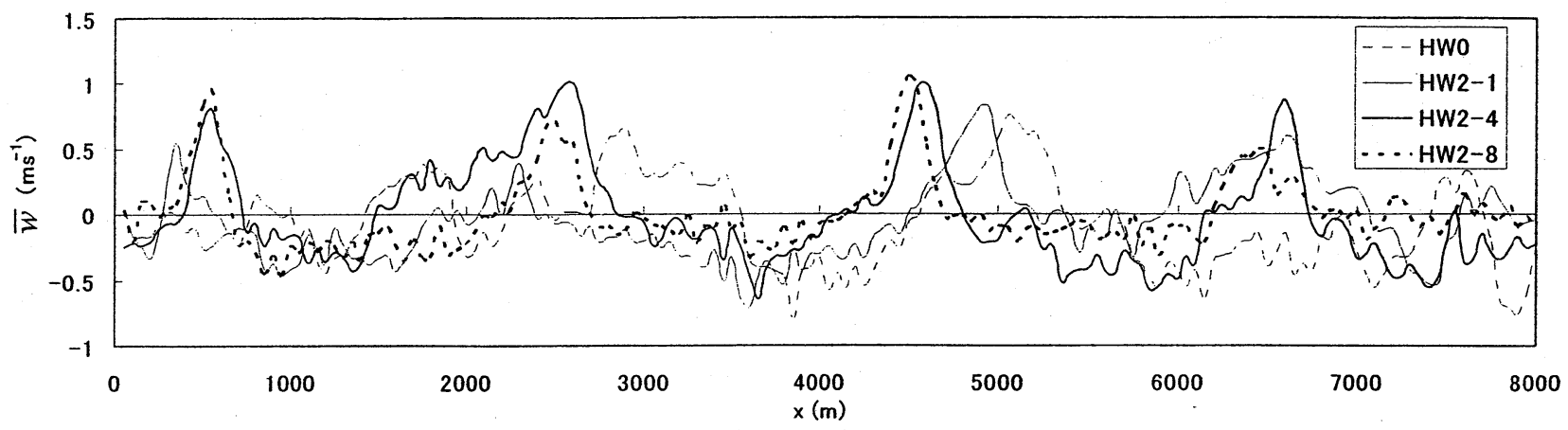

(a) 平均鉛直風速

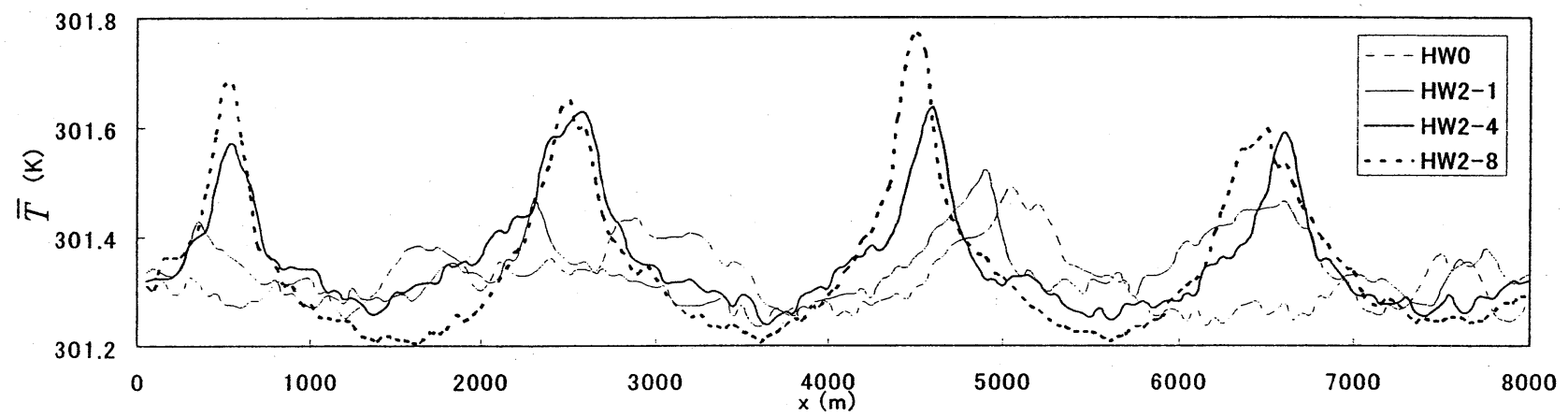

(b) 平均温位

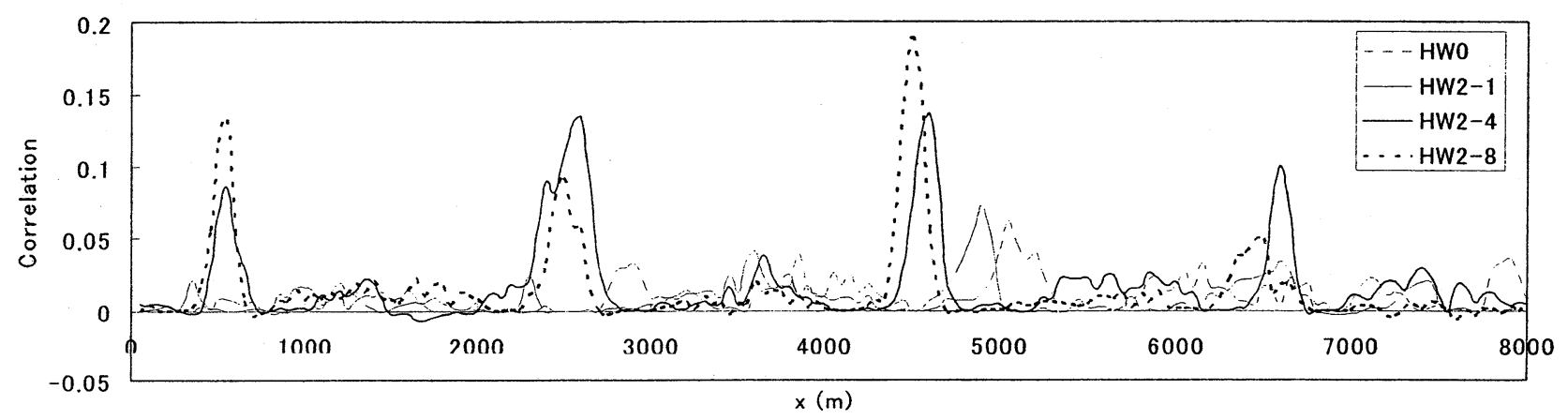

(c) 平均鉛直風速と平均温位の相関

図-4 各種統計量のx方向分布 $(z=100 m, y=4000 m)$

ここで図-3における弱い加熱振幅によりインバラン スが若干減少することについて考えるため、一様加熱 と加熱振幅の弱い例 (HW4-2) を比較してみる。場全体で の $\bar{w} と \bar{T}$ の相関図(図5)を見てみると、一様加熱 (図$5(\mathrm{a}))$ ではほぼ一直線に分布しているのに対し、弱い加 熱振幅(図-5(b))では上昇流域(正の $\bar{w}$ ) で相関が少し乱 れている。つまり温位が小さなところで上昇流が発生 しており、上昇流の輸送効率が減少することが示され ている。さらに領域全体での相関(式(10))を計算した。

$$
\rho_{\bar{w} \bar{T}}=\frac{\sum_{i=1}^{n}\left(\bar{w}_{i}-[\bar{w}]\right)\left(\bar{T}_{i}-[\bar{T}]\right)}{\sigma_{\bar{w}} \sigma_{\bar{T}}}
$$

$n:$ 水平断面格子点数

その結果一様加熱では0.92、HW4-2では0.86であり、 確かに場全体を見た時の相関は弱い加熱振幅を持つ方 が小さくなっている。図-1 (a)に示されるような一様加 熱が作り出す構造は線形安定性理論で示されるような
最大発達率を与える擾乱によって選択的に自己組織化 された構造パターンであり ${ }^{7}$ 、最も効率の良い熱輸送が 行われる。この構造は加熱条件によらず、実際の気象 場ではアスペクト比2.00ものが最も安定である。この ため不均一性により任意的に定められた構造パターン では熱輸送の効率が下がったものと考えられる。

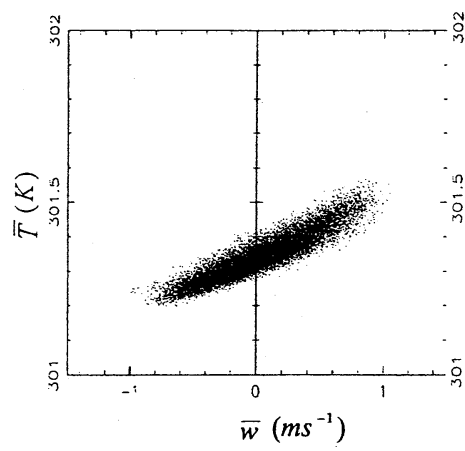

(a) 振幅0 (HWO)

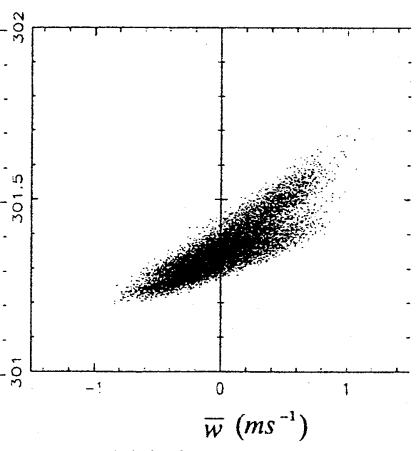

(b) 振幅20\% (HW4-2)
図-5 平均鉛直風速と平均温位の相関図 


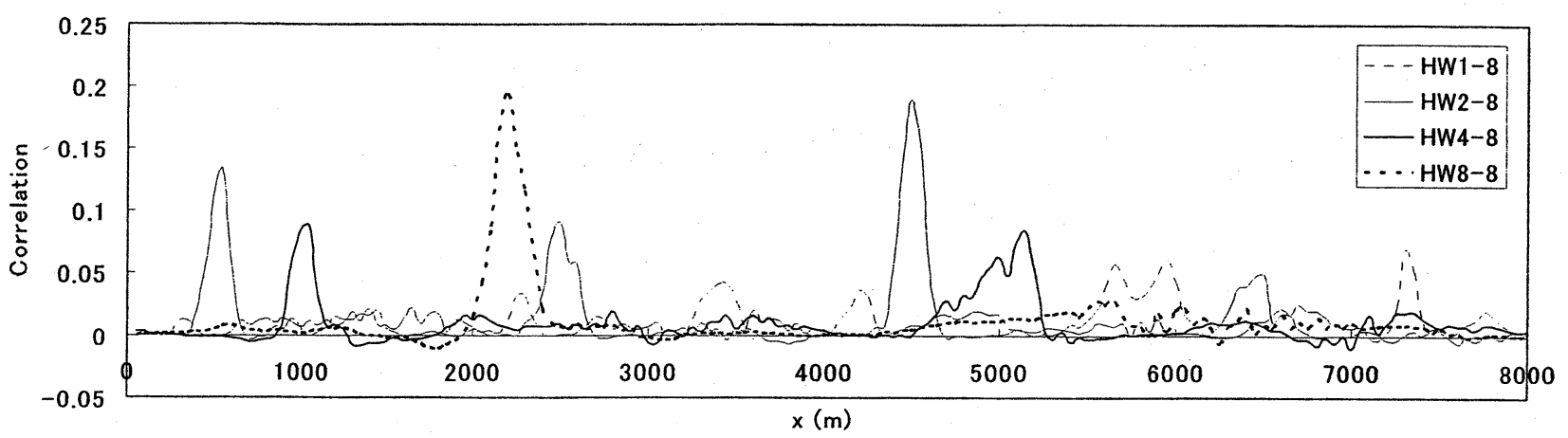

図-8 平均鉛直風速と平均温位の相関の $x$ 方向分布 $(z=100 \mathrm{~m}, \mathrm{y}=4000 \mathrm{~m})$

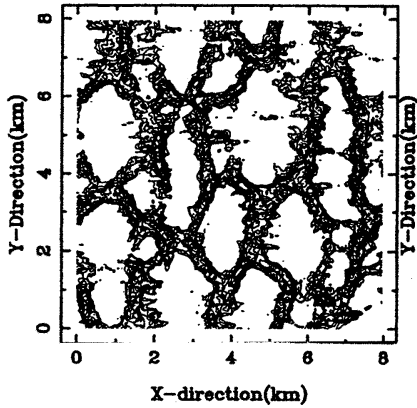

(a) 波長 $1 \mathrm{~km}(\mathrm{HW1}-8)$

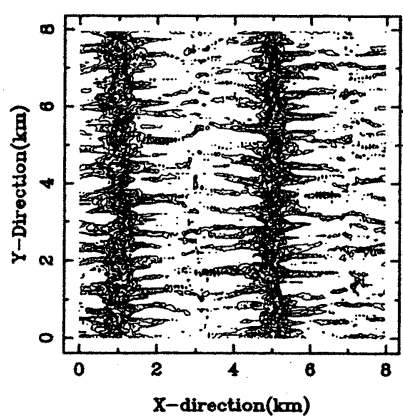

(c) 波長 $4 \mathrm{~km}$ (HW4-8)

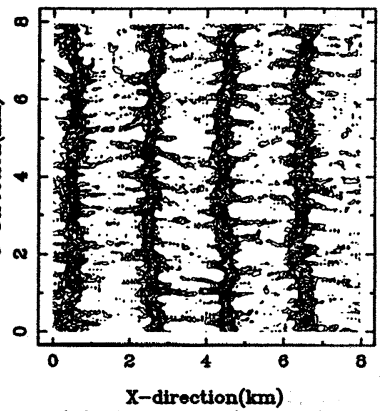

(b) 波長 $2 \mathrm{~km}$ (HW2-8)

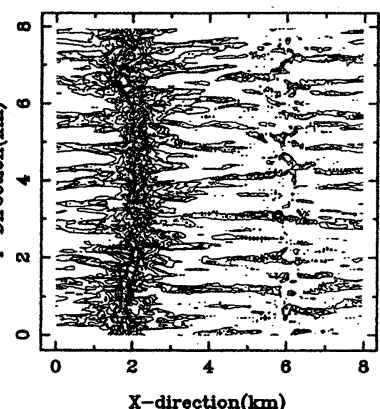

(d) 波長8 $8 \mathrm{~km}$ (HW8-8)

図-6 平均鉛直風速分布 (上昇流域)

\section{（2）加熱波長の影響}

加熱パターンの変化がインバランスに対しどのよ うな影響をもたらすか検討する。方法として正弦関 数変化で与えている底面加熱の波長 $\lambda$ を変化させ る。与えた波長は周期境界条件の関係から領域の 方向長さ $(8 \mathrm{~km})$ を割り切れる值となっている。

平均鉛直流構造は図-6のようになった。そしてこ のような場に生じるインバランスの空間平均值は 図-7のようになった。これによると加熱波長 $2 \mathrm{~km}$ の 時に大きなインバランスが生じるようであるが、こ の原因は何であろうか。これを検討するため、図-7 で加熱波長による変化の最も大きい加熱振幅 $80 \%$ の 計算例に対し、先程と同様に $\mathrm{y}=4 \mathrm{~km}$ の位置における $\bar{w}$ と $\bar{T}$ の相関のx方向変化(図-8)を見てみる。する と加熱波長 $2 \mathrm{~km}$ のとき他に比べ非常に大きな平均 流の熱輸送効率が生じている。一般に局地循環の空 間スケールが大きな程平均流による熱輸送は増加す ると考えられるが、加熱波長 $2 \mathrm{~km}$ での局所的な值は 加熱波長 $8 \mathrm{~km}$ での值と大差ない。その原因を考える。

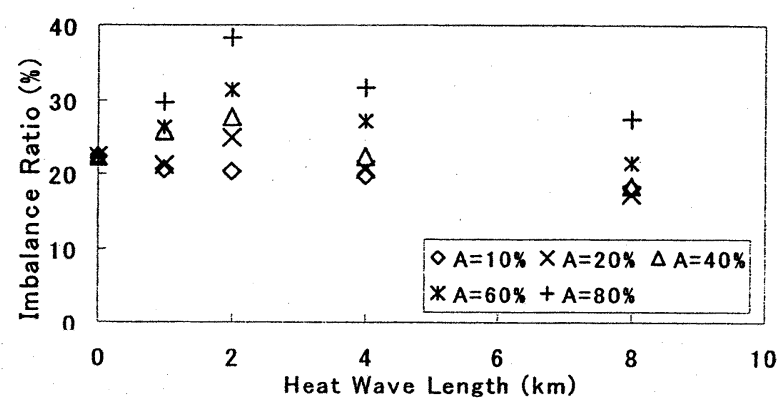

図-7 空間平均インバランス率と加熱波長の関係

本数值計算は晴れた日中を想定した計算であり、 そのような場で発達しやすいサーマル構造のアスペ クト比は約2.0であることが知られている。その構 造の鉛直スケールを定める境界層高度はどの加熱波 長でも約 $1 \mathrm{~km}$ である。また非一様加熱における局地 循環の水平スケールを定めるのは加熱波長である。 つまりそれが $2 \mathrm{~km}$ ときアスペクト比が2.0となるた め、局地循環自体が最も発達しやすい状態となり、 局地循環による非常に大きな熱輸送効率が生じたも のと考えられる。

\section{（3）平均化時間比較}

平均化時間を変えることで一様加熱、非一様加熱 におけるデータがそれぞれどのように変化するか比 較検討を行う。計算開始後から1時間のデー夕、ま た 3 時間のデー夕を平均化し比較する。その結果を 表-3に示す。

一様加熱では平均化時間を長くすると、インバラ ンスの空間平均值は減少するが標準偏差は増加する。 これは温位の乱流成分 $T^{\prime}$ が場の温度上昇トレンド の影響を受けて、長時間とるほどT'が増加するた めである。そして表-3より加熱に不均一性がある場 合も同様の結果が得られており、また一様加熱と同 様の説明をつけることができる。

しかし $[i b r]$ の值を見てみると、3時間平均では弱 い加熱波長 (HW4-2) より、一様加熱による值の方が 小さくなっている。これは不均一な加熱による局地 循環の時間スケールが3時間以上であるためと考え られる。

次にインバランス率の標準偏差を見ると、今度は 
表-3 平均化時間別各種統計值

\begin{tabular}{|c|c|c|c|}
\hline Case & $\begin{array}{c}\text { 平均化時間 } \\
\text { (hour) }\end{array}$ & $\begin{array}{c}{[i b r]} \\
(\%)\end{array}$ & $\begin{array}{c}\sigma_{i b} \\
(\%)\end{array}$ \\
\hline \multirow{2}{*}{ HW0 } & 1 & 22.24 & 46.61 \\
\cline { 2 - 4 } & 3 & 9.63 & 60.27 \\
\hline \multirow{2}{*}{ HW4-2 } & 1 & 20.54 & 44.58 \\
\cline { 2 - 4 } & 3 & 12.28 & 53.99 \\
\hline
\end{tabular}

表-4 水平一般風の風向別各種統計値

\begin{tabular}{|c|c|c|}
\hline Case & $\begin{array}{c}\text { インバランス率 }[i b r] \\
(\%)\end{array}$ & $\begin{array}{c}\text { 標準偏差 } \\
(\%)\end{array}$ \\
\hline HW4-2u2 & 4.22 & 28.42 \\
\hline $\mathrm{HW} 4-2 \mathrm{v} 2$ & 11.26 & 28.60 \\
\hline
\end{tabular}

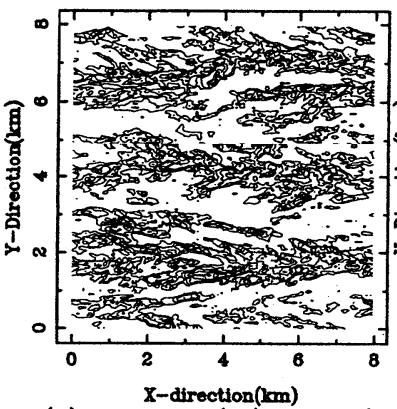

(a) $U g=2.0 \mathrm{~ms}^{-1}$ (HW4-2u2)

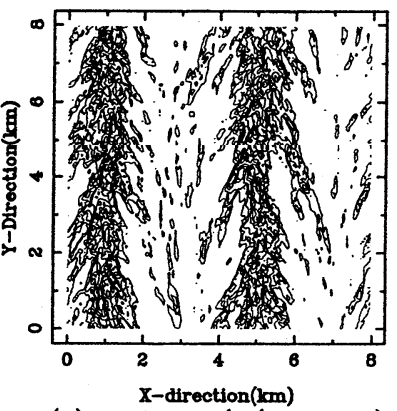

(b) $\mathrm{Vg}=2.0 \mathrm{~ms}^{-1}(\mathrm{HW} 4-2 \mathrm{v} 2)$
図-9 平均鉛直風速分布（上昇流域）

逆に非一様加熱のほうが長時間平均したときの值が 小さくなっている。局所的に大きなインバランスが 生じるのは、鉛直風速と温位の時系列変化が互いに 強い正負の相関をなすときであると、神田 (2002) ${ }^{4)}$ は述べている。つまり非一様加熱では平均鉛直流構 造が比較的停帯することにより局所的な鉛直風速卜 レンドが生じにくくなるためであると考えられる。

\section{（4）水平一般風の影響}

縞状の加熱に対し、それに平行方向 $(\mathrm{x}-\mathrm{di} \mathrm{r})$ 、垂 直方向 $(y-d i r)$ に対し、風速 $2 \mathrm{~ms}^{-1}$ の水平一般風を加 えた。その結果は表-4のように、縞に対し垂直方向 に一般風が吹く時 (HW4-2u2) が大きくインバランス を改善することが分かった。この原因は図-9を見る と明らかであり、縞に対し垂直に吹く時は強い加熱 部にできる平均流構造を場全体に移流するのに対し、 縞に平行に吹く場合には縞に沿って移流するだけで、 元の平均流構造が残るため平均鈶直風速もあまり減 少しないためである。

\section{5. 結論}

以上の結果より非一様な加熱を与えた場に生じる インバランスに対し、次のような結論が得られた。

(1) 加熱の不均一性が非常に強いとき、負のインバ ランスを発生する傾向も強くなる。これは強い 加熱部における平均流熱輸送が圧倒的に増大し、 正味の熱輸送を押し上げるためである。加熱の 不均一性が弱いとき、それほどの強い輸送は生 じず、必ずしもインバランスは増加しない。
(2) 加熱パターンが $2 \mathrm{~km}$ のきに最も大きなインバ ランスが生じる。これはこのとき生じる平均鉛 直流構造のアスペクト比が約2.0であり、日中 の大気条件でもつとも効率よく発達できる形状 である。そのため強い平均鉛直流が生じ、温位 との強い相関を生み出したためである。

(3) 一様加熱、非一様加熱ともに平均化時間を長く するとインバランスの空間平均值は減少するが、 その標準偏差は増加する。しかし平均流構造が 変化することにより、循環の時間スケールも変 化することにより効果は異なる。

(4) 水平一般風が吹くときインバランスは改善され るが、場が不均一であるときは一般風の吹く方 向によって改善される度合いが変わってくる。 不均一な加熱では常に上昇流が生じ易い所、下 降流が生じ易い所が分かれるため、両者が良く 混ざるような方向に吹くとき最も改善される。

謝辞 : 本論では文部科学省科学研究費補助金基盤研究 （B）（2）（課題番号：12450197）、科学技術振興事業団 戦略的基礎研究推進事業(代表 : 神田学)による財政的援 助を受けました。ここに記して謝意を申し上げます。

\section{参考文献}

1) Twine, T. E. , Kus tas, W. , Norman, J. M. , Cook, D. R., Houser, P. R., Meyers, T. P., Prueger, J.H. ,

Starks, P.J., Wesley, M.L. : Correcting eddy covariance flux underestimates over a grassland, Agric. For. Meteorol., 103, pp. 279-300, 2000.

2) Lee, $X:$ on micrometeorological observations of surface-air exchange over tall vegetation, Agric. For. Meteorol., 91, pp. 39-49, 1998.

3) 神田学・渡辺力・マルコスオルッル・シギーフリードラッシュ： LESによる熱収支インバランス問題に対する検討 （第1報）大気境界層スケールの対流構造の影響, 水文・水資源学会誌, vol.15,No.3, pp.243-252,2002

4) 神田学・稲垣厚至・マルコスオレッルル・シギーフリードラッシュ : 点計測乱流量の空間代表制に関する理論的検討一 インバランス問題の物理的解釈-, 水工学論文集, 第46巻, 2002

5) Raasch, S. and Schroter, M. : PALM --- A large-eddy simulation model performing on massively parallel computers. Meteorol. Z., 10, pp. 363-372, 2001.

6) Deardorff, J.W.: Stratocumulus capped mixed layer derived from a three-dimensional model, Boundary-Layer Meteorol., 18, pp.495527,1980 .

7) 木村竜治, 地球流体力学入門, 1983

8) Albertson, J.D. and Parlange, M. B. : Natural integration of scalar fluxes from complex terrain, Advances in. Water Resour., 23,pp. 239-252, 1999

（2002. 9. 30受付） 